Pakistan Journal of Nutrition 12 (11): 957-959, 2013

ISSN 1680-5194

(C) Asian Network for Scientific Information, 2013

\title{
Nutritional and Antinutritional Components of Vetiver Grass (Chrysopogon zizanioides L. Roberty) at Different Stages of Growth
}

\author{
O.O. Falola ${ }^{1}$, M.C. Alasa ${ }^{2}$, A.J. Amuda ${ }^{3}$ and O.J. Babayemi ${ }^{3}$ \\ ${ }^{1}$ Federal College of Animal Health and Production Technology, \\ P.M.B 5029, Moor Plantation, Ibadan, Oyo State, Nigeria \\ ${ }^{2}$ Federal College of Education (Special), Oyo State, Nigeria \\ ${ }^{3}$ Department of Animal Science, University of Ibadan, Ibadan, Nigeria
}

\begin{abstract}
Vetiver grass was harvested at 4,6 and 8-week old re-growth. The chemical composition and quantitative analyses of anti-nutritional components were determined. The result showed that dry matter and fiber content increased with age while crude protein, mineral content and anti-nutritional components reduced with age. It was concluded that age of re-growth significantly affect the nutrient and anti-nutrients contents of vetiver grass.
\end{abstract}

Key words: Vetiver grass, age of regrowth, nutrients and anti-nutrients components

\section{INTRODUCTION}

Chrysopogon zizanoides commonly known as vetiver is a perennial grass of poaceae family, native of India. It can grow up to 1.5 meters high, the stems are tall and leaves are long, thin and rigid, unlike most grasses which form horizontally spreading mat-like root systems vetiver roots grow downward, 2-4 meters deep. It has a key attribute to drought resistance, ability to grow on infertile soils and its deep and thick roots systems allowing wide adaptability (Truog and Baker, 1998), though a native of India, vetiver is widely cultivated in the tropical region of the world. The main purpose of growing it is for soil and water conservation. Recent works by scientists have brought vetiver grass into other uses which include forage for livestock grazing, compost, cooling effect, water purification, botanical pesticides and fragrance. Liu and Cheng (2003) in an experiment observed that vetiver grass is edible herbage of high quality in their growing stages for ruminants. The leaves of vetiver are useful to feed cattle, sheep, goats and horses. The nutritional contents depend on season, growth stage and soil fertility. This study aimed to determine the nutrient and anti-nutritional components of vetiver grass at different stages of growth so as to provide basic data for nutrient evaluation or future application of vetiver as ruminants feed.

\section{MATERIALS AND METHODS}

Samples of 4, 6 and 8 week old re-growth of vetiver were harvested from an existing experimental plot at F.C.A.H and PT, Moor-plantation, Ibadan the samples were oven dried to a constant weight and ground into powders.

Chemical analysis: Dried samples were analyzed for crude protein, crude fibre, ether extract and ash according to (AOAC, 1990). Neutral detergent fiber, acid detergent fiber and acid detergent lignin were determined as described by Van Soest et al. (1991). After ashing of samples in a muffle furnace at $550^{\circ} \mathrm{C}$, mineral analyses of calcium and potassium were determined using Atomic Absorption Spectrophotometer while sodium was read in flame photometer and phosphorus was read in flame spectrophotometer. Quantitative determination of tannins, saponnins, oxalates, phenol and phytates were also carried out in triplicates, Saponin was analyzed by method of AOAC (1990), Phytate was determined according to Maga (1983) method. Tannin and oxalate were analyzed by Beutler et al. (1980).

Statistical analysis: Data obtained were subjected to one way analysis of variance (ANOVA) using SAS (1999), Means were compared using Duncan (1955) option of same software.

\section{RESULTS AND DISCUSSION}

The chemical composition of vetiver grass is given in Table 1. The Dry matter content of vetiver grass obtained ranged from $31.09-38.92 \%$, the values were higher than the range reported by Nguyen et al. (2004) and lower than the report of Aderinola et al. (2008). It was observed that dry matter components increased with age and values were higher than the values reported for Panicum maximum (Ajayi, 2007) and Pennisetum purpureum (Okaraonye and Ikewuchi, 2009). This could be due to the period of harvest, soil fertility and geographical location. Crude protein was also decreasing with age and the CP content of vetiver at 4-week of re-growth was lower than the report of Aderinola et al. (2008) and Nguyen et al. (2004) for vetiver. The values obtained 
Pak. J. Nutr., 12 (11): 957-959, 2013

Table 1: Chemical composition of vetiver grass at 4,6 and 8 week re-growths

\begin{tabular}{lllll}
\hline Parameters & 4 week & 6 week & 8 week & \pm SEM \\
\hline Dry matter & $31.09^{\mathrm{c}}$ & $33.72^{\mathrm{b}}$ & $38.92^{\mathrm{a}}$ & 0.61 \\
Crude protein & $8.38^{\mathrm{a}}$ & $7.10^{\mathrm{b}}$ & $5.38^{\mathrm{c}}$ & 0.49 \\
Crude fiber & $23.59^{\mathrm{c}}$ & $24.66^{\mathrm{b}}$ & $28.67^{\mathrm{a}}$ & 0.71 \\
Ether extract & $6.66^{\mathrm{c}}$ & $7.02^{\mathrm{b}}$ & $7.87^{\mathrm{a}}$ & 0.31 \\
Ash & $8.48^{\mathrm{a}}$ & $7.70^{\mathrm{b}}$ & $6.53^{\mathrm{c}}$ & 0.24 \\
NFE & 52.89 & 53.52 & 51.55 & 2.87 \\
NDF & $56.41^{\mathrm{c}}$ & $60.53^{\mathrm{b}}$ & $68.76^{\mathrm{a}}$ & 2.27 \\
ADF & $34.35^{\mathrm{c}}$ & $37.39^{\mathrm{b}}$ & $38.75^{\mathrm{a}}$ & 0.47 \\
ADL & $7.60^{\mathrm{c}}$ & $8.42^{\mathrm{b}}$ & $8.61^{\mathrm{a}}$ & 0.18 \\
\hline
\end{tabular}

$\mathrm{SEM}=$ Standard error of means.

${ }^{a, b, c}$ means with different superscripts on the same row are significantly different $(p<0.05)$. NDF: Neutral detergent Fiber, ADF: Acid detergent fiber, ADL: Acid detergent lignin

Table 2: Mineral contents ( $/ 100 \mathrm{~g} \mathrm{DM}$ ) of 4,6 and 8 week regrowths of vetiver grass

\begin{tabular}{lllll}
\hline Parameters & 4 week & 6 week & 8 week & \pm SEM \\
\hline Calcium & $0.55^{\mathrm{a}}$ & $0.49^{\mathrm{b}}$ & $0.42^{\mathrm{c}}$ & 0.02 \\
Phosphorus & $0.28^{\mathrm{a}}$ & $0.24^{\mathrm{b}}$ & $0.19^{\mathrm{c}}$ & 0.02 \\
Sodium & $0.30^{\mathrm{a}}$ & $0.22^{\mathrm{b}}$ & $0.16^{\mathrm{c}}$ & 0.02 \\
Potassium & $1.54^{\mathrm{a}}$ & $1.54^{\mathrm{b}}$ & $1.12^{\mathrm{c}}$ & 0.03 \\
\hline
\end{tabular}

SEM $=$ standard error of means.

${ }^{a, b, c}$ means with different superscripts on the same row are significantly different $(p<0.05)$

Table 2: Anti-nutritional factors ( $\mathrm{mg} / 100 \mathrm{~g} \mathrm{DM})$ in 4,6 and 8 week re-growths of vetiver grass

\begin{tabular}{lllll}
\hline Parameters & 4 week & 6 week & 8 week & \pm SEM \\
\hline Saponin & $0.55^{\mathrm{a}}$ & $0.46^{\mathrm{b}}$ & $0.37^{\mathrm{c}}$ & 0.02 \\
Tannin & $0.66^{\mathrm{a}}$ & $0.58^{\mathrm{b}}$ & $0.50^{\mathrm{c}}$ & 0.02 \\
Phytate & $0.64^{\mathrm{a}}$ & $0.56^{\mathrm{b}}$ & $0.49^{\mathrm{c}}$ & 0.02 \\
Phenol & $0.32^{\mathrm{a}}$ & $0.24^{\mathrm{b}}$ & $0.20^{\mathrm{c}}$ & 0.05 \\
Oxalate & $0.33^{\mathrm{a}}$ & $0.24^{\mathrm{b}}$ & $0.19^{\mathrm{c}}$ & 0.03 \\
\hline
\end{tabular}

SEM $=$ standard error of means.

$a, b, c$, means on the same row with different superscripts are significantly $(p<0.05)$ different

were also lower than the values reported for panicum maximum (Ajayi, 2007) and Pennisetum purpureum (Okaraonye and Ikewuchi, 2009) but the values obtained at 4 weeks $(8.38 \%)$ can meet the daily protein requirement of $7 \%$ for ruminants (NRC, 1981). The crude fibre contents also increased with age and the values were high compared to values reported for Panicum maximum (Ajayi, 2007) and values reported for pennisetum purpureum (Okaraonye and ikewuchi, 2009). The result obtained agreed with the report of Odedire and Babayemi (2008) who reported that tropical forages are characterized by fast lignifications and low protein content as they advance in age. The ash content and ether-extract of vetiver obtained in this study were comparable to values reported elsewhere.

The values obtained for calcium, phosphorus, sodium and potassium declined with age. Mineral decline in age has been reported in tropical grasses (Babayemi et al., 2006 and McDonald et al., 1995). This decline in age may be due to the effect of dilution of these elements in a great quantity of dry matter that is produced and accumulated with advancing age. Gomide (1978) associated the high concentration of Phosphorus and potassium in young tissues to their being mobile and thus easily translocate from the oldest tissue to the young ones.

The values obtained for $\mathrm{Ca}(0.55-0.42 \%)$ in this study were within the range $(0.40-1.5 \%)$ recommended for goats but below $1.6 \%$ recommended for lactating goats (NRC, 1981). The values $(0.28-0.19 \%)$ obtained for $P$ were above minimum range of $0.15 \%$ recommend for ruminant (NRC, 1981). Na content ranged from (0.30$0.16 \%)$ and was within the recommended requirement for ruminants (NRC, 1981). Values (1.54-1.12\%) obtained for $\mathrm{K}$ was above the $0.80 \%$ recommended for lactating goats and $0.50 \%$ recommended for maintenance and non-lactating goats (NRC, 1981).

The concentrations of some of the anti-nutrients were given in Table 3. The concentration were increasing with age, the levels of saponnins were lower than values $(0.85 \%)$ reported for pennisetum purpureum (Okaraonye and Ikewuchi, 2009) and higher than values reported for Panicum maximum (Ajayi, 2007). Saponnins reduce intake of the feed and uptake of certain nutrients including glucose and cholesterol. From the level obtained in this study it is not likely that the saponnin content of vetiver will affect its nutritional potentials to any significant extent. The levels of tannins reported here were lower than values (28.64\%) reported for Pennisetum purpureum (Okaraonye and Ikewuchi, 2009) and Panicum maximum (Ajayi, 2007). The level of tannin which adversely affect digestibility in sheep and cattle is between 2 and 5\% (Diagayette and Huss, 1981). Goats are known to have threshold capacity of about $9 \%$ dietary tannin (Natis and Malachek, 1981). The levels of oxalates observed here range from $0.13 \mathrm{mg} / 100 \mathrm{~g}$ to $0.32 \mathrm{mg} / 100 \mathrm{~g}$ and is unlikely to pose toxicity problems, since it is below $2-5 \mathrm{~g}$ (Oke, 1969). Oxalate affects $\mathrm{Ca}$ and $\mathrm{Mg}$ metabolism (Onwuka, 1983) but ruminants can consume considerable amounts of high oxalate plants without adverse effects due principally to microbial decomposition in the rumen (Oke, 1969). The phytate levels observed were higher than $(0.16 \%)$ reported for penninsetum purpurem. The knowledge of the phytate level in feeds is necessary because high concentration can cause adverse effects on the digestibility of minerals (Nwokolo and Bragg, 1977). Phytate forms stable complexes with $\mathrm{Cu}^{2+}, \mathrm{Zn}^{2+}, \mathrm{Co}^{2+}, \mathrm{Mn}^{2+}, \mathrm{Fe}^{2+}$ and $\mathrm{Ca}^{2+}$.

Conclusion: The values obtained in terms of protein and mineral content at 4 and 6-week of re-growths contained adequate amount of nutrients for livestock requirements and the anti-nutritional contents were below the toxic level. It is necessary to apply strategic harvesting procedure in order to enhance the nutritive capacity of the grass to support livestock production. 
Pak. J. Nutr., 12 (11): 957-959, 2013

\section{REFERENCES}

Aderinola, O.A., J.A. Akinlade, T.A. Rafiu and T. Fajinmi, 2008. Feed intake, digestibility and nitrogen balance of west African dwarf sheep and goat fed Vetiveria nigritana grass. Proceedings of 33rd annual conference of Nigerian society for animal production (2008), OOU Ayetoro, pp: 579-582.

Ajayi, F.T., 2007. Nutritional evaluation of Panicum maximum (cv Ntchisi) intercropped with some legumes for West African Dwarf goats . Ph.D Thesis University of Ibadan, Ibadan, Nigeria.

AOAC, 1990. Official Methods of Analysis. 15th Edn., Association of Analytical Chemists. WashIngton D.C, USA.

Babayemi, O.J., F.T. Ajayi, A.A. Taiwo, M.A. Bamikole and A.K. Fajimi, 2006. Performance of West African dwarf goat fed Panicum maximum and concentrate diet supplemented with Lablab purpureus, Leucaena leucocephala and Gliricidia sepium foliage. Nig. J. Anim. Prod., 29: 199-206.

Beutler, H.O., J. Beeker, G. Micheal and E. walter, 1980. Rapid method for the determination of oxalate. Fresenius J. Analytical Chem., pp: 301-187.

Diagayette, M. and W. Huss, 1981. Tannin contents of African pasture plants. Effects on analytical data and in vitro digestibility. Anim. Res. Dev., 15: 79-90.

Duncan, D.B., 1955. Multiple range and multiple F-test. Biometics, 11: 1-42.

Gomide, J.A., 1978. Mineral composition of grasses and tropical leguminous forages, In Latin American symposiumon mineral nutrition research with grazing ruminants Gainseville, University of Florida, pp: 3240.

Liu, J.X. and Y. Cheng, 2003. Issues of utilization andprotection of formative vetiver grass pratacultural science 19.

Maga, J.A., 1983. Phyatate: its chemistry, occurrence, food interactions nutritional significance and method analyses. J. Agric. Food Chem., 30: 1-9.

McDonald, P., R.A. Edward and J.F.D. Greenhalgh, 1995. Animal nutrition, 5th Edn., Longman Scientific and Technical, England.
Natis, A.S. and J.C. Malachek, 1981. Digestion and utilization of nutrients oak browse by goats. J. Anim. Sci., 52: 283-288.

Nguyen, V.H, T.H.N. Nguyen, A.Q. VO and V.N. Pham, 2004. Digestibility of Nutrient Content of Vetiver grass by Goats Raised in the Mekong Delta, Vietnam. www. Vetiver.org/proceeding/nhanpdf.

NRC, 1981. Nutrients requirement of goat; Angora dairy and meat goat in temperate and tropical continent. Nutrient requirement of Domestic animals.

Nwokolo, E.N. and B.B. Bragg, 1977. Influence of phytic acid and crude fiber on the availability of minerals from protein supplements in growing chicks. J. Anim. Sci., 57: 475-477.

Odedire, J.A. and O.J. Babayemi, 2008. Comparative study on the yield and chemical composition of Panicum Maximum and Andropogon Gayanus as influenced by Tephrosia candida and Leucaena leucocephala. Livestock Res. Rural Dev. Volume 20, article \#27. Retrieve july 22, 2009 from http://www.irrd.org/irrd20/2/oded20027.htm.

Okaraonye, C.C. and J.C. Ikewuchi, 2009. Nutritional and Antinutritional components of Pennisetum purpureum (schumach). Pak. J. Nutr., 8: 32-34.

Oke, O.L., 1969. Oxalic acids in plants and in nutrition. World Rev. Nutr. Dietetics, 10: 263-303.

Onwuka, C.F., 1983. Nutritional evaluation of some Nigeria browse plants in the humid tropics. Ph.D Thesis University of Ibadan, Ibadan, Nigeria.

SAS, 1999. Statistical analytical system institute, SAS/STAT User's guide statistical, SAS Institute, Cary. North Carolina, USA.

Troug, P.V. and D. Baker, 1998. Vetiver grass system for environmental protection technology. Bulletin No.1998/1PVV/ORDPB, Bangkok, Thailand.

Van Soest, P.J., J.B. Robertson and B.A. Lewis, 1991. Methods for dietary fibre, neutral Detergent fiber and non-starch polysaccharides in relation to animal nutrition. J. Dairy Sci., 74: 3583-3597. 